\title{
Rescuing the extinction of experience
}

Michael J. Samways

Department of Conservation Ecology and Entomology, Centre for Invasion Biology, University of Stellenbosch, Matieland, 7602, South Africa

\section{Beyond instrumental value}

Miller (2005) and Stokes (2006) draw our attention to a crucial issue: humans are losing touch with nature, particularly in the urban environment. Miller (2005) has called this the 'extinction of experience'. We are on the threshold between a real world and a virtual world, which is disconnecting us and nature. The outcome is a loss of appreciation of our reliance on nature. As we are an intrinsic part of the world around us, there are some issues requiring close focus before we embark on a rescue of the extinction of experience.

Conservation biology's traditional viewpoint is that biodiversity is the variety of life; structural, compositional and functional, from genes to ecosystems (Noss 1990). This is a biotic everything, sometimes leading to the view that it thus has little hard currency. Nevertheless, this approach is a good working framework for initial conceptualization of biodiversity, as well as the scaffolding for scientific studies. Although scientific light is being shed on the structure, composition and functioning of biodiversity, its concept seems at times to have little value in the eyes of the public. For everyone to value biodiversity, which is an essential underpinning to its conservation (Wilson 1984), the closest we can get is to feel nature (Rothenberg 1989) and to love it (Fox 1993; Stokes 2006). This may not be the language of reductionist science, although it is the language of biodiversity appreciation and revival, through inculcation of experience, to which Miller (2005) and Stokes (2006) refer.

\section{Urban environments and experiencing nature}

Studies undertaken independently in different countries have shown (Harrison and Burgess 2000; Rozzi et al. 2000; Soran et al. 2000) how important it is to involve all players, from the outset of a conservation enterprise. Most of this planning is about, and for, adults, or their future generations. But what is the value of biodiversity for children per se, as Miller (2005) points out? Interestingly, in a public survey in a botanical garden towards development of a dragonfly observation trail, it was the children and the elderly that were most interested in the animals, with the economically active adults the least interested (Suh and Samways 2001). Children were particularly intrigued by dragonflies and other insects, which intrinsically function at a physical dimension to which they can relate. In their eyes, dragonflies were also very tangible, especially when they could put their fingers in the net and feel the larvae in the mud.

Urban parks can be a valuable source of positive feelings and beneficial services (Chiesura 2004). However, there is a downside for biodiversity conservation when children experience nature only in the urban environment. They are effectively exposed just to common, widespread and generalist species, with the specialists relegated to the remnants of wilderness (Ferreira and Tidon 2005). This gives a false sense, particularly of rare, irreplaceable biodiversity. Nevertheless, there is still the experience of nature which, as Miller (2005) says, children will carry through to adulthood. Then perhaps is the right time for full appreciation of the nuances of endemism and its conservation.

A further consideration is the level of expectation from nature. As wise people have said for centuries, we can only expect change from nature. While change is part of the freshness of nature, for the public in 
general, there is also an expectation of nature's deliverables. Game reserves are a case in point, with their attractiveness being not just about landscapes but also the chances of seeing charismatic animals.

One way to address reliability in an urban reserve is to have a suite of 'core resident species' (Niba and Samways 2006), which are those species which are likely to be seen on any one visit. These are the 'certs' of twitchers. Yet total predictability can also be dull, and so as with any game viewing or bird watching, it is always exciting to have a few charismatic rarities. So we need to encourage some of the rarer species into our urban midst, which is the job of scientific conservation biologists. This approach benefits both biodiversity and human sensitivities. Having said that, we also need to consider cultural viewpoints on particular landscapes (Palmer and Finlay 2003) as well as recognize landscape icons such as special trees, paths or hedges (Gobster 2001).

So how then do we encourage experience while practicing good science? As Midgley (2001) shows us, science has its reason and place, and so does the poetry of nature. Science does the designing of the landscape using well-investigated principles of conservation biology, while valuing nature (Rolston 1994) provides the motivation and the goodness. These two approaches are not mutually exclusive. Indeed, linking them improves conservation efforts. The exclusivity of scientific conservation then holds hands with the common cultural language of humankind and the common good. Together, scientific conservation biology and a sense of nature is reason to the conservation effort.

Yet urban conservation with all its goodness and its value in rescuing the extinction of experience does not generally value the very rare, threatened and specialized species. These imperiled species may be threatened by urbanization, but rescuing the extinction of experience does not generally help them directly. They are the stuff of the Red List, and glorious in their own right (Baillie et al. 2004), with each species requiring special care to enable its recovery. Recovery for some may be in an urban setting (Samways 2006) but by and large they need the full benefits of wilderness. As recently emphasized by De Grammont and Cuarón (2006) and Rodrigues et al. (2006), the Red List has enormous conservation value for species conservation. The point is that rescuing the extinction of experience and rescuing threatened species are highly complementary activities, one activity benefiting people and their relationship with nature (the biophilia of Wilson (1984)) and the other a specialist activity which respects the intrinsic value of individual species and their survival.

\section{References}

Baillie JEM, Hilton-Taylor C, Stuart S (eds) (2004) A global species assessment. IUCN, Cambridge, UK

Chiesura A (2004) The role of urban parks for the sustainable city. Landsc Urban Plan 68:129-138

De Grammont PC, Cuarón AD (2006) An evaluation of threatened species categorization systems used on the American continent. Conserv Biol 20:14-27

Ferreira LB, Tidon R (2005) Colonizing potential of Drosophilidae (Insecta, Diptera) in environments with different grades of urbanization. Biodivers Conserv 14:1809-1821

Fox W (1993) Why care about the world around us? Resurgence 161:10-12

Gobster PH (2001) Visions of nature: conflict and compatibility in urban park restoration. Landsc Urban Plan 56:35-51 
Harrison C, Burgess J (2000) Valuing nature in context: the contribution of common-good approaches. Biodivers Conserv 9:1115-1130

Midgley M (2001) Science and poetry. Routledge, London and New York

Miller JR (2005) Biodiversity conservation and the extinction of experience. Trend Ecol Evol 20:430-434

Niba AS, Samways MJ (2006) Development of the concept of 'core resident species' for quality assurance of an insect reserve. Biodivers Conserv 15:4181-4196

Noss RF (1990) Indicators for monitoring biodiversity: a hierarchical approach. Conserv Biol 4:355-364

Palmer M, Finlay V (2003) Faith in conservation. The World Bank, Washington DC, USA

Rodrigues ASL, Pilgrim JD, Lamoreux JF, Hoffmann M, Brooks TM (2006) The value of the IUCN Red List for conservation. Trend Ecol Evol 21:71-76

Rolston H III (1994) Conserving natural value. Columbia University Press, New York

Rothenberg D (1989) Introduction: ecosophy T - from institution to system. In: Naess A (ed) Ecology, community and lifestyle. Cambridge University Press, Cambridge, United Kingdom, pp $1-22$

Rozzi R, Silander J Jr, Armesto JJ, Feinsinger P, Massardo F (2000) Three levels of integrating ecology with the conservation of South American temperate forests: the initiative of the Institute of Ecological Research Chiloe, Chile. Biodivers Conserv 9:1199-1217

Samways MJ (2006) Insect extinctions, and insect survival. Conserv Biol 20:245-246

Soran V, Biro J, Moldovan O, Ardelean A (2000) Conservation of biodiversity in Romania. Biodivers Conserv 9:1187-1198

Stokes DL (2006) Conservators of experience. BioScience 56:6-7

Suh AN, Samways MJ (2001) Development of a dragonfly awareness trail in an African botanical garden. Biol Conserv 100:345-353

Wilson EO (1984) Biophilia. Harvard University Press. Cambridge, Massachusetts 